DOI: http://dx.doi.org/10.12957/demetra.2014.14064

\title{
Divulgando nova chamada de artigos para número temático voltado para "Diálogos no campo da Antropologia da Alimentação"
}

\section{Disseminating new call for papers for a thematic issue on "Dialogues in the field of Food Anthropology"}

Iniciamos este editorial desejando a todos uma boa leitura e agradecendo a leitores e autores por seu apoio nos avanços e na divulgação da nossa revista.

O recebimento de um volume cada vez maior de originais se mantém consistente, o que nos permitiu publicar, neste número, 15 artigos originais de alta qualidade, além de cinco resumos de teses e dissertações defendidas no Programas de Pós-graduação em Alimentação, Nutrição e Saúde do Instituto de Nutrição da UERJ, abordando objetos que identificam o campo da Alimentação e Nutrição no Brasil, a saber: comida, alimento e/ou nutriente.

Os artigos originais se desdobram em temas oriundos dos diversos núcleos de saberes que conformam o campo científico da Alimentação e Nutrição, como um estudo sobre identidade social do obeso, outro situado no âmbito das Políticas de Alimentação e Nutrição, dois estudos epidemiológicos sobre Nutrição, dois estudos sobre a produção refeições, um estudo sobre composição química e qualidade microbiológica dos alimentos e, por fim, oito estudos da área da Nutrição Clínica.

Manter a trajetória de crescimento da Demetra é parte muito importante de nossa política editorial. Em oportunidade anterior, investimos com sucesso na divulgação de estudos que articulavam saberes e práticas no âmbito da Alimentação e das Humanidades. Prosseguindo nessa linha, gostaríamos de anunciar nosso próximo investimento: a preparação de um número especial que privilegiará o debate acerca de saberes e práticas alimentares que têm como tema central os diálogos com a Antropologia da Alimentação.

Nesse novo número temático, a ser publicado em 2015, pretendemos oportunizar a divulgação de pesquisas e reflexões que abordem estudos sobre os significativos arranjos sociais e culturais dos mais diversos grupamentos humanos, revelados a partir das análises de práticas alimentares. 
Muito animados e movidos pelas melhores expectativas, anunciamos e agradecemos a parceria com os pesquisadores Martín César Tempass, da Universidade Federal de Pelotas, e Mônica Chaves Abdala, da Universidade Federal de Uberlândia, na coordenação desse promissor número temático.

Esperamos que o novo número temático contribua para a consolidação de maior interlocução entre as Ciências Humanas e Sociais e as Ciências da Saúde nas pesquisas sobre alimentação. Dessa forma, convidamos nutricionistas, antropólogos, sociólogos, historiadores, psicólogos, entre outros profissionais, para dialogar sobre o tema que convoca olhares multidisciplinares.

Contamos, mais uma vez, com a confiança dos pesquisadores ao enviar seus trabalhos para divulgação e na colaboração com o fortalecimento de nossa revista, comprometida em oportunizar a todos o acesso público e gratuito ao conhecimento produzido pela ciência.

Fabiana Bom Kraemer e Shirley Donizete Prado 